\title{
PRAWO DO POSZANOWANIA UCZUĆ RELIGIJNYCH W ŚWIETLE KONWENCJI O OCHRONIE PRAW CZLOWIEKA I PODSTAWOWYCH WOLNOŚCI
}

\section{WPROWADZENIE}

Przedmiotem niniejszego artykułu jest kwestia, czy z wolności religii można wywodzić prawo osób wierzących do ochrony ich uczuć religijnych, a jeśli tak, to $\mathrm{w}$ jakim stopniu ochrona tego prawa może usprawiedliwiać ograniczenie wolności słowa. Jak wiadomo, wolność religii polega w swej istocie na nieskrępowanej możliwości wyboru wyznania (aspekt wewnętrzny) oraz uzewnętrzniania tego wyznania przez różnego rodzaju praktyki religijne, w szczególności modlitwę, udział w rytuałach i obrzędach, noszenie charakterystycznego ubioru czy nauczanie (aspekt zewnętrzny) ${ }^{1}$. Z kolei wolność słowa polega na uzewnętrznianiu własnych poglądów, np. na politykę, kwestie społeczne, moralność, religię czy inne tematy, a także na gromadzeniu i rozpowszechnianiu informacji o faktach (ten ostatni element ma znaczenie zwłaszcza dla wolności mediów). Ochronie prawnej podlegają nie tylko wypowiedzi werbalne (ustne i pisemne), lecz także tzw. wypowiedzi symboliczne, czyli wszelkie inne formy ekspresji komunikujące określoną informację bądź ideę, np.: obraz, zdjęcie, rzeźba, występ uliczny itd. ${ }^{2}$ Co istotne, wolność słowa obejmuje także możliwość wygłaszania poglądów, które „obrażaja, oburzają lub wprowadzają niepokój w państwie lub części społeczeństwa” ${ }^{3}$. Oczywistą konsekwencją korzystania $\mathrm{z}$ wolności słowa przez daną osobę jest ingerencja $\mathrm{w}$ prawa i wolności innych osób - prawo do dobrego imienia, prawo do prywatności czy właśnie prawo do poszanowania uczuć religijnych.

${ }^{1} \mathrm{Z}$ obszernej literatury na temat samej wolności myśli, sumienia i religii zob. np. następujace monografie: Warchałowski (2004); Hucał (2012); Sobczak (2013).

${ }^{2}$ Szerzej zob. np. Nowińska (2007); Wacławczyk (2009); Skrzydło (2013); Bychawska-Siniarska (2017).

${ }^{3}$ Słynny wyrok ETPC z 7 grudnia 1976 r., Handyside p. Zjednoczonemu Królestwu: § 49. W sprawach dotyczących wolności prasy Trybunał zwracał też uwagę, że ochroną konwencyjna objęte są także wypowiedzi prowokacyjne, wyolbrzymiające, stronnicze - wyr. ETPC z 26 kwietnia 1995 r., Prager i Obershlick p. Austrii: § 38; wyr. ETPC z 22 lutego 2007 r., Standard Verlagsgesellschaft $m b H(n r .2)$ p. Austrii: $\S 40$. Wszystkie cytowane w artykule orzeczenia ETPC sa dostępne w internetowej bazie HUDOC: <hudoc.echr.coe.int>. 
Pojęcie prawa do poszanowania ochrony uczuć religijnych nie występuje w Konwencji o ochronie praw człowieka i podstawowych wolności (Europejskiej Konwencji Praw Człowieka, EKPC), ani w żadnym z dołaczonych do niej protokołów. Moim zdaniem istnieją jednak poważne podstawy do wywiedzenia takiego uprawnienia z wolności religijnej wyrażonej w art. 9 EKPC. Po pierwsze, dlatego że w wielu systemach prawnych osoby wierzące wyposażono w prawne instrumenty ochrony ich uczuć, np. możliwość wytoczenia powództwa o ochronę dóbr osobistych czy domagania się ścigania przestępstwa bluźnierstwa bądź obrazy uczuć religijnych. Świadczy to o istnieniu wśród państw członkowskich Rady Europy przekonania, że uczucia religijne stanowią wartość prawną zasługującą na pewną ochronę. Po drugie, od wielu lat w orzecznictwie Europejskiego Trybunału Praw Człowieka (ETPC) traktuje się uczucia religijne jako przesłankę usprawiedliwiającą ograniczenie wolności słowa. Tematyka ta z pewnością zasługuje na głębszą refleksję.

\section{WOLNOŚĆ SLOWA A WOLNOŚĆ OBRAŻANIA}

W dyskusji na temat ochrony uczuć religijnych pada pytanie, czy w czasach współczesnych, w dobie pluralizmu, w ogóle istnieje „prawo do nieobrażania przekonań religijnych" ". Moim zdaniem to pytanie należy odwrócić - czy istnieje prawo do obrażania kogokolwiek z jakiegokolwiek powodu? „Obrazić” (ang. insult, offend) oznacza „uchybić czyjejś godności osobistej słowem lub czynem”, „zwracać się do kogoś lub traktować kogoś bez szacunku, z pogarda”“, „powiedzieć lub zrobić coś prymitywnego i odpychającego"7. „Prawo do obrażania” w sensie językowym oznacza zatem prawo do grubiaństwa, w tym prawa do używania inwektyw i wulgaryzmów oraz do upokarzania i okazywania pogardy innym ludziom. Z całą pewnościa żaden akt prawny nie mówi wprost o takim prawie. Wiele aktów prawnych mówi natomiast o wolności wypowiedzi, wolności wyrażania przekonań czy po prostu wolności słowa i to z tej wolności zwykło się wyprowadzać tzw. prawo do obrażania (right to insult) ${ }^{8}$.

Nie zawsze tak było. W średniowieczu wolność słowa przejawiała się w wolności badań naukowych na uniwersytetach, w czasach nowożytnych zaczęto ja wiązać z prawem do krytykowania nadużyć władzy, następnie rozszerzono ja na prawo do krytykowania także osób prywatnych, a dopiero w czasach współczesnych uznano, że każdy ma także prawo do obrażania innych. W moim

${ }^{4}$ Letsas (2012): 239-260.

${ }^{5}$ Słownik PWN, <https://sjp.pwn.pl/szukaj/obrazić.html> [dostęp: 2.02.2020].

${ }^{6}$ Według słownika oksfordzkiego - „insult” oznacza „speak to or treat with disrespect or scornful abuse", <https://en.oxforddictionaries.com/definition/insult> [dostęp: 2.02.2020].

${ }^{7}$ Według słownika Cambridge - „insult” oznacza „to say or do something to someone that is rude and offensive", <https://dictionary.cambridge.org/dictionary/english-polish/insult_1> [dostęp: 2.02.2020].

${ }^{8}$ Szerzej na ten temat Clooney, Webb (2017): 1-55. 
przekonaniu „prawo” do obrażania jest na tyle dalekie od pierwotnej idei wolności słowa, że nie powinno być traktowane jako wynikające z godności ludzkiej, przyrodzone i niezbywalne prawo człowieka.

Dopiero w czasach współczesnych za sprawą Sądu Najwyższego Stanów Zjednoczonych i Europejskiego Trybunału Praw Człowieka (najbardziej chyba wpływowych w cywilizacji zachodniej sądów konstytucyjnych) zaczęto przyjmować, że wolno nie tylko krytykować, ale również obrażać. „Słowo” nie musi przynosić pożytku - stało się wartością samą w sobie. To oczywiście nie oznacza, że wolność słowa jest dziśs wartością absolutną - podlega ona proporcjonalnym ograniczeniom, niemniej ma ona znacznie szerszy zakres niż w pierwotnej idei praw człowieka. W praktyce jednak uznaje się, że „słowem” wyjętym spod ochrony prawa sa tylko wypowiedzi najbardziej radykalne: mowa nienawiści oraz oczywiste oszczerstwa. Dlatego też prawa człowieka we współczesnym rozumieniu nie stoja na przeszkodzie cywilnym, a nawet karnym sankcjom za mowę nienawiści i oszczerstwa. Natomiast wszystkie pozostałe „słowa” nawet te najbardziej prymitywne i wulgarne - mogą co do zasady liczyć na ochronę prawną.

Nie godzę się z takim kierunkiem ewolucji standardu wolności słowa. Prawo nie powinno chronić wypowiedzi skrajnie prymitywnych lub majacych na celu wyłącznie upokorzenie drugiego człowieka - podkreślam tu słowo „wyłącznie”, aby zaznaczyć, że z całą pewnością ochronie powinny podlegać wypowiedzi kontrowersyjne i szokujące, jeśli kryje się za nimi jakiś argument merytoryczny, jeśli wnoszą one choćby minimalny wkład do debaty publicznej.

Przez wypowiedzi prymitywne lub służące wyłącznie upokorzeniu drugiego człowieka mam na myśli wypowiedzi obrażające uczucia religijne, ale także wypowiedzi obrażajace człowieka jako takiego. Trudno uznać za „fundamentalny warunek rozwoju społeczeństwa i każdego człowieka” (wyrok w sprawie Handyside) tolerowanie wypowiedzi wyzywajacych innych od „chamów”9 i „idiotów” 10 czy prymitywnych wystaw przedstawiajacych osoby publiczne na tle męskich lub żeńskich genitaliów ${ }^{11}$. Podzielam pogląd wyrażony przez sędziów ETPC w Strasburgu Franza Matschera i Thóra Vilhjálmssona, według których celem art. 10 Konwencji „,jest umożliwienie realnej wymiany idei,

9 Por. wypowiedź Janusza Palikota, który powiedział, że „uważa prezydenta [Lecha Kaczyńskiego] za chama” nie została uznana za znieważenie głowy państwa. Prokurature przekonały mało poważne wyjaśnienia samego Palikota, który zeznał, że określenia „cham” w stosunku do prezydenta użył w znaczeniu określonym w biblijnej przypowieści o Chamie, synu Noego, przez co chciał podkreślić, iż zachowanie prezydenta było niegodne i niestosowne - postanowienie Sądu Okręgowego w Warszawie z 9 lutego 2009 r., XVIII Kp 841/08.

${ }^{10} \mathrm{~W}$ z 1 lipca 1997 r., Oberschlick p. Austrii ( $n r$ 2), ETPC uznał, że w pewnych okolicznościach nawet użycie obraźliwego określenia, takiego jak ,idiota”, mieści się w granicach akceptowanej swobody wypowiedzi, gdyż radykalne, szokujące działania lub wypowiedzi polityka moga spowodować ostry komentarz.

${ }^{11}$ W z 15 stycznia 2019 r., Mătăsaru p. Mołdawii, ETPC uznał za pogwałcenie wolności słowa skazanie na 2 lata więzienia w zawieszeniu na 3 lata mężczyzny, który na ulicy przed siedzibą prokuratury generalnej wystawił dwie „rzeźby” w kształcie penisa i łechtaczki; powiesił na nich zdjęcia wysokich urzędników państwowych. 
a nie ochrona prymitywnego, niskiej jakości dziennikarstwa, które nie mając kwalifikacji do sformułowania poważnych argumentów, odwołuje się do prowokacji i niepotrzebnych obelg w celu przyciagnięcia potencjalnych czytelników, nie wnosząc żadnego wkładu w wymianę idei, które zasługują na takie określenie"12. Pogląd ten można odnieść również do wypowiedzi osób niebędących dziennikarzami.

Brak podstaw do ochrony zachowań prymitywnych, wulgarnych i grubiańskich, co oczywiście nie oznacza, że powinny one być sankcjonowane w dowolny sposób. W państwie prawa każde działanie organu władzy publicznej musi być proporcjonalne do wagi naruszenia. Dlatego też uważam, że najwłaściwszej formy sankcji dla tego rodzaju wypowiedzi należy szukać w prawie cywilnym, ograniczając sankcje karne i administracyjne wyłącznie do wypowiedzi powodujących poważne niepokoje społeczne zagrażające porządkowi publicznemu lub nawołujących do przemocy.

\section{PRAWO DO OCHRONY UCZUĆ RELIGIJNYCH W EKPC}

Europejska konwencja praw człowieka nigdzie wprost nie odnosi się do ochrony uczuć religijnych. Mimo to można przyjąć ostrożną tezę, że w świetle orzecznictwa ETPC art. 9 wykładany systemowo w związku z art. 10 ust. 2 EKPC uprawnia do przyjęcia, że wolność religii obejmuje również prawo do ochrony uczuć religijnych.

Zgodnie z art. 10 ust. 2 EKPC korzystanie z wolności wypowiedzi pociaga za soba „obowiązi i odpowiedzialność” i może podlegać takim wymogom formalnym, warunkom, ograniczeniom i sankcjom, jakie sa przewidziane przez ustawę i niezbędne w społeczeństwie demokratycznym w interesie bezpieczeństwa państwowego, integralności terytorialnej lub bezpieczeństwa publicznego ze względu na konieczność zapobieżenia zakłóceniu porządku lub przestępstwu, z uwagi na ochronę zdrowia i moralności, ochronę dobrego imienia i praw innych osób oraz ze względu na zapobieżenie ujawnieniu informacji poufnych lub na zagwarantowanie powagi i bezstronności władzy sądowej.

W utrwalonym od lat dziewięćdziesiątych orzecznictwie ETPC przyjmuje się, że pojęcie praw innych osób obejmuje także prawo do ochrony uczuć religijnych, które sam Trybunał określa jako:

- prawo obywateli do nieurażania ich uczuć religijnych (,the right of citizens not to be insulted in their religious feelings") ${ }^{13}$;

12 Zdanie odrębne sędziów Franza Matschera i Thóra Vilhjálmssona do wyroku ETPC z 1 lipca 1997 r., Oberschlick p. Austrii (nr 2).

${ }^{13}$ Wyrok ETPC z 20 września 1994 r., Otto-Preminger-Institut p. Austrii: § 48, który notabene jest zaliczany do „wielkich precedensów strasburskich” mających istotny wpływ na kształtowanie się standardu w dziedzinie wolności słowa - komentarz do art. 10: Garlicki, Hofmański, Wróbel (2010). 
- ochronę przeciwko traktowaniu przedmiotu religijnego w pogardliwy, piętnujący, obraźliwy, kłamliwy lub ośmieszający sposób (,,protection against the treatment of a religious subject in contemptuous, reviling, insulting, scurrilous or ludicrous manner") $)^{14}$;

- prawo innych osób do odpowiedniego poszanowania ich wolności myśli, sumienia i religii (,the right of other persons to proper respect for their freedom of thought, conscience and religion") ${ }^{15}$;

- prawo do poszanowania doktryn i wierzeń religijnych innych osób (,the right to respect for the religious doctrines and beliefs of others") ${ }^{16}$;

- prawo do poszanowania uczuć religijnych osób wierzących (,the right to respect for the religious feelings of believers") ${ }^{17}$;

- prawa innych osób, których uczucia religijne zostały urażone (,rights of other persons whose religious feelings were offended") ${ }^{18}$;

- prawo do ochrony przed zniesławieniem grupy osób z powodu ich przynależności do określonej religii (,right to protection of a group of persons from defamation on account of their membership of a specific religion") ${ }^{19}$.

Z kolei w pojęciu „zapobiegania zakłóceniom porządku”, o którym mowa w art. 10 ust. 2 EKPC, mieści się także zabezpieczenie pokoju religijnego (safeguarding religious peace $)^{20}$.

W świetle dotychczasowego orzecznictwa prawo do ochrony uczuć religijnych ujmowane jest raczej jako wartość, na którą prawodawca krajowy może się powołać, ograniczając wolność słowa, niż jako samodzielne prawo podmiotowe. Sam ETPC nigdy nie stwierdził wprost, że z art. 9 EKPC wynika prawo do poszanowania uczuć religijnych (choć będzie miał ku temu okazję, o czym mowa poniżej). Z tego punktu widzenia można mówić raczej o „rozwijającym się prawie" (developing right) do ochrony uczuć religijnych, ograniczonym do sytuacji, gdy atakuje się je świadomie oraz w sposób bezproduktywnie obraźliwy. Trybunał w Strasburgu na razie jeszcze „nie wykreował pozytywnego prawa, na którym mogliby się oprzeć liczni skarżący, ale raczej przyznał państwom szeroki margines swobody w podejmowaniu działań na rzecz ochrony uczuć religijnych członków społeczeństwa, nawet jeśli to ogranicza prawa takie jak wolność wyrażania przekonań”"1.

${ }^{14}$ Wyrok ETPC z 25 listopada 1996 r., Wingrove p. Zjednoczonemu Królestwu: § 48 - także zaliczany do wielkich precedensów.

${ }_{15}$ Wyroki ETPC: z 13 września 2005 r., I.A. p. Turcji: § 2 7; z 20 września 1994 r., Otto-Preminger-Institut p. Austrii: § 55; z 2 maja 2006 r., Aydin Tatlav p. Turcji: § 26; z 25 października 2018 r., E. S. p. Austrii: $\S 46$.

${ }^{16}$ Wyrok ETPC z 10 lipca 2003 r., Murphy p. Irlandii: § 63-64.

${ }_{17}$ Postanowienie Europejskiej Komisji Praw Człowieka z 18 kwietnia 1997 r., Dubowska i Skup p. Polsce.

${ }_{18}$ Wyrok ETPC z 31 października 2006 r., Klein p. Stowacji: § 45.

${ }^{19}$ Wyrok ETPC z 31 stycznia 2006 r., Giniewski p. Francji: § 40-42.

${ }^{20}$ Wyrok ETPC z 25 października 2018 r., E. S. p. Austrii: $§ 41$.

${ }^{21}$ Evans (2001): 69-71. 


\section{Ocena niezbędności ingerencji w wolność wypowiedzi}

W orzecznictwie strasburskim przyjęto, że ocena, czy ingerencja w wolność wypowiedzi była „niezbędna w społeczeństwie demokratycznym” w rozumieniu art. 10 ust. 2 EKPC wymaga ustalenia, czy:

1) stanowiła ona odpowiedź na naglącą potrzebę społeczną (pressing social need);

2) była proporcjonalna w stosunku do pożądanego celu (istotne znaczenie na tym etapie ma potencjalny zasięg medium, za pomocą którego doszło do upublicznienia wypowiedzi);

3) powody podane przez władze krajowe jako uzasadnienie działania były istotne i wystarczajace (relevant and sufficient).

W ocenie, czy istnieje „nagląca potrzeba”, państwom przysługuje pewien margines swobody, do czego jeszcze wrócę ${ }^{22}$.

\section{Obowiązek unikania bezproduktywnie obraźliwych wypowiedzi}

Dokonując oceny „konieczności” ingerencji w wolność słowa, ETPC uwzględnia obowiązki ciążące na jednostkach korzystające $\mathrm{z}$ uprawnień zagwarantowanych w art. 10 EKPC. Zgodnie z utrwalonym orzecznictwem ETPC, art. 10 EKPC wyraża obowiązek unikania wypowiedzi, które jako bezproduktywnie obraźliwe (gratuitously offensive) lub wulgarne (profane) nie przyczyniają się w żaden sposób do debaty publicznej ${ }^{23}$. W związku z powyższym państwo może uznać za konieczne wprowadzenie środków represyjnych wobec pewnych form zachowań, w tym również rozpowszechniania informacji lub idei, uznanych za niezgodne z poszanowaniem wolności myśli, sumienia i wyznania ${ }^{24}$.

$\mathrm{Z}$ art. 10 Konwencji może wiązać się również obowiązek unikania wypowiedzi mających religijny charakter, które choć same w sobie nie są obraźliwe, to w konkretnych okolicznościach moga wywołać obraźliwy skutek. Władze publiczne mogą być wówczas uprawnione do ingerencji w wolność wypowiedzi w celu uniknięcia obrazy uczuć religijnych. Przykładowo ETPC w jednej sprawie uznał, że całkowity zakaz emisji nagrań o charakterze religijnym w paś-

${ }^{22}$ Wyroki ETPC: z 7 grudnia 1976 r., Handyside p. Zjednoczonemu Królestwu: § 48; z 26 kwietnia 1979 r., Sunday Times p. Zjednoczonemu Królestwu (nr 1): § 62; z 4 grudnia 2003 r., Gündüz p. Turcji: § 38; z 31 stycznia 2006 r., Giniewski p. Francji: § 43-54; z 2 maja 2006 r., Aydin Tatlav p. Turcji: § 22-27; z 10 lipca 2003 r., Murphy p. Irlandii: § 65-69.

${ }^{23}$ Wyroki ETPC z: 20 września 1994 r., Otto-Preminger-Institut p. Austrii: § 49; 25 listopada 1996 r., Wingrove p. Zjednoczonemu Królestwu: 52; 13 września 2005 r., I.A. p. Turcji: § 24; 4 grudnia 2003 r., Gündüz p. Turcji: § 37; 31 stycznia 2006 r., Giniewski p. Francji: $\S$ 43; 31 października 2006 r., Klein p. Stowacji: § 45; 29 kwietnia 2008 r., Kutlular p. Turcji: $\S$ 47; 30 stycznia 2018 r., Sekmadienis Ltd. p. Litwie: $\S 74 ; 25$ października 2018 r., E. S. p. Austrii: $\S 43$.

${ }^{24}$ Zob. w kontekście art. 9 EKPC - z 25 maja 1993 r., Kokkinakis p. Grecji. Zob. także wyroki: z 20 września 1994 r., Otto-Preminger-Institut p. Austrii: § 47; z 13 września 2005 r., I.A. p. Turcji: § 26; z 2 maja 2006 r., Aydin Tatlav p. Turcji: § 25; z 25 października 2018 r., E.S. p. Austrii: $§ 45$. 
mie reklamowym może w społeczeństwie wyjątkowo wrażliwym na punkcie religii i potencjalnej obawy przed prozelityzmem zostać usprawiedliwiony ochrona poszanowania uczuć religijnych ${ }^{25}$.

\section{Pozytywny obowiązek ochrony uczuć religijnych}

Kwestia, czy z art. 9 EKPC wynika pozytywny obowiązek państwa do ochrony wolności religijnej, jest obecnie dyskusyjna. Obowiązek państwa ograniczano do aspektu negatywnego, tj. powstrzymania się od ingerencji w wolność religijna, natomiast nie rozszerzano go o obowiązek stworzenia jej „warunków do rozkwitu”26, czyli atmosfery przyjaznej dla wyznawania religii, wolnej od prymitywnej i wulgarnej krytyki. Innymi słowy, według obecnego stanu orzecznictwa, państwo może chronić osoby wierzace przed obrażaniem uczuć religijnych, natomiast nierozstrzygnięta pozostaje kwestia, czy państwo ma w pewnych przypadkach taki obowiązek. Z całą pewnością można powiedzieć, że wedle communis opinio orzecznictwa oraz nauki prawa europejskiego państwa mają na mocy art. 9 EKPC pozytywny obowiązek ochrony pokoju religijnego ${ }^{27}$.

Przez pokój religijny należy rozumieć bezkonfliktowe współistnienie wszystkich religii oraz osób bezwyznaniowych przez zagwarantowanie wzajemnej tolerancji. Chodzi tu przede wszystkim o zapobieganie wypowiedziom i zachowaniom, które mogłyby sprowokować wyznawców określonej religii do aktów agresji, doprowadzić do wybuchu konfliktu między różnymi grupami społecznymi i co za tym idzie - zniechęcać do wyznawania określonej religii z obawy przed prześladowaniami. Jak trafnie wskazuje się w literaturze: „Oczywiście, nikt nie może rozsądnie oczekiwać, że jego przekonania religijne i światopoglądowe będą wyłączone spod wszelkiej krytyki. [...] Można sobie jednak wyobrazić sytuacje, w których krytyka przeradza się w pozbawione treści pasmo zniewag lub gdy ktoś podejmuje działania zmierzajace do utrudnienia bądź uniemożliwienia drugiej osobie korzystania z jej wolności, np. przez przeszkadzanie w uroczystości religijnej. Zaatakowany może wówczas oczekiwać od państwa podjęcia interwencji w jego sprawie" 28 .

Nie ma jednak powszechnej zgody co do tego, czy państwo powinno również ingerować w wolność słowa w celu ochrony wyznawców religii przed obrazą ich uczuć, nawet w braku zagrożenia dla pokoju społecznego - o ile sam

${ }^{25}$ Wyrok ETPC z 10 lipca 2003 r., Murphy p. Irlandii: § 63-64, 72-74, 77.

${ }_{26}$ Evans (2001): 69.

27 Wyrok ETPC z 10 listopada 2005 r., Leyla Şahin p. Turcji: § 107-108, oraz z 1 lipca 2014 r., S.A.S. p. Francji: § 123-128. Zob. także wyrok z 25 października 2018 r., E.S. p. Austrii: $\S 44$. Z literatury zob. van Dijk, Fvan Hoof, van Rijn, Zwaak (2018): 755; Meyer-Ladewig, Nettesheim, von Raumer (2017): 377; Schabas (2015): 421-422; Frowein, Peukert (1996): 371-372; komentarz do art. 9, Garlicki, Hofmański, Wróbel (2010); Evans (2001): 71-72; Uitz (2007): 149, $153-154$.

28 Brzozowski, Krzywoń, Wiącek (2019): 211. 
ETPC wydaje się uznawać to za dopuszczalne, o tyle wielu przedstawicieli doktryny pozostaje krytycznie nastawionych do tego stanowiska ${ }^{29}$.

Osobiście nie podzielam dość powszechnego krytycyzmu doktryny do strasburskiej koncepcji bezproduktywnej obraźliwości. Tak jak już wspominałem, w moim przekonaniu, w demokratycznym społeczeństwie brak wartości, które przemawiałyby za przyznawaniem ochrony wypowiedziom mającym na celu wyłącznie upokorzenie innego człowieka. Dlatego też państwo powinno chronić nie tylko pokój religijny, ale - z zachowaniem odpowiednich proporcji - także uczucia religijne wierzacych przed niepotrzebnie obraźliwymi wypowiedziami.

\section{Margines swobody}

W czasach współczesnych aktualny pozostaje pogląd ETPC wyrażony w latach osiemdziesiątych i dziewięćdziesiątych, zgodnie z którym nie jest możliwe ustalenie jednolitej koncepcji istotności moralności i religii w społeczeństwie ${ }^{30}$. W konsekwencji brak jednego, uniwersalnego podejścia państw co do potrzeby ochrony praw osób wierzących przed atakami na uczucia religijne poszerza margines swobody krajowych prawodawców przy regulowaniu wolności wypowiedzi w sferach, w których może ona doprowadzić do obrazy intymnych osobistych przekonań moralnych lub religijnych ${ }^{31}$. Stanowisko to Trybunał w Strasburgu potwierdził ostatnio w 2018 r. w wyroku E.S. p. Austrii (§ 44).

W konsekwencji przyjmuje się, że z uwagi na bezpośredni i stały kontakt z żywiołami społecznymi wewnątrz swoich państw, władze krajowe co do zasady znajdują się w lepszej pozycji niż sędzia międzynarodowy, gdy przychodzi wyrazić opinię na temat wymogów co do granic korzystania z wolności wypowiedzi, jak również „niezbędności” ograniczenia tej wolności i dla zapewnienia ochrony przed materiałami, które mogą poważnie urazić najgłębsze uczucia i przekonania ${ }^{32}$.

Oceniając zasadność ingerencji w wolność wypowiedzi w celu ochrony wolności religijnej innych osób, ETPC brał pod uwagę między innymi liczebność osób wierzących na obszarze, w którym doszło do ograniczenia wolności wypowiedzi. Przykładowo w sprawie Otto-Preminger-Institut p. Austrii ETPC przy ocenie dopuszczalności zakazu emisji filmu naruszającego uczucia religijne uwzględnił fakt, że religia rzymskokatolicka była wyznaniem przytłaczającej większości mieszkańców ( $(56)$. W sprawie Murphy p. Irlandii ETPC przy ocenie dopuszczalności zakazu emisji ogłoszenia radiowego o planowanym wy-

${ }^{29}$ Uitz (2007): 151-164. Zob. też krytyczne uwagi do wyroku E.S. p. Austrii, uznającego dopuszczalność ograniczenia wolności słowa w imię ochrony uczuć religijnych - Smet (2018); Milanovic (2018); Peers (2018).

${ }^{30}$ Wyroki ETPC: z 24 maja 1988 r. Müller i inni p. Szwajcarii: § 35; z 20 września 1994 r., Otto-Preminger-Institut p. Austrii: $\$ 50$.

${ }^{31}$ Wyroki ETPC: z 2 maja 2006 r., Aydin Tatlav p. Turcji: § 24; z 20 września 1994 r., Otto-Preminger-Institut p. Austrii: § 50; z 25 listopada 1996 r., Wingrove p. Zjednoczonemu Królestwu: $\S 53$ i 58; z 10 lipca 2003 r., Murphy p. Irlandii: § 67; z 13 września 2005 r., I.A. p. Turcji: § 25.

32 Wyroki ETPC: z 25 listopada 1996 r., Wingrove p. Zjednoczonemu Królestwu: § 58; z 10 lipca 2003 r., Murphy p. Zjednoczonemu Królestwu: § 67. 
kładzie na temat zmartwychwstania Chrystusa brał pod uwagę szczególna wrażliwość irlandzkiego społeczeństwa na sprawy religijne i na potencjalny prozelityzm ${ }^{33}$.

$\mathrm{Na}$ podstawie analizowanego orzecznictwa można wywieść wniosek, że dla oceny konieczności ingerencji w wolność słowa w celu ochrony uczuć religijnych istotną rolę ma zatem kontekst społeczno-kulturowy, w szczególności stosunek danego społeczeństwa do religii.

\section{Przykłady dopuszczalnych ingerencji w wolność wypowiedzi w celu ochrony uczuć religijnych}

Za niezbędne dla ochrony uczuć religijnych i pokoju religijnego ETPC uznał na przykład następujące ingerencje w wolność wypowiedzi:

- konfiskatę filmu zawierającego prowokacyjne sceny z udziałem postaci kultu religijnego, przedstawiających Boga Ojca jako zniedołężniałego starca padającego na twarz przed diabłem, a następnie wymieniającego z nim namiętny pocałunek; Jezusa Chrystusa jako osobę niepełnosprawną intelektualnie, pożądliwie obściskującego piersi jego matki, Maryi; Maryję wsłuchująca się z wypiekami na twarzy w słowa diabła, który czyta jej opowiadanie pornograficzne ${ }^{34}$

- całkowity zakaz dystrybucji filmu przedstawiającego rzekome fantazje erotyczne św. Teresy z Ávila

- zakaz nadawania w radiu ogłoszenia zapowiadającego emisję filmu o dowodach na zmartwychwstanie Chrystusa ${ }^{36}$;

- nałożenie grzywny w wysokości 3291000 lirów tureckich (stanowiących wówczas równowartość 16 dolarów amerykańskich) za opublikowanie książki, w której znalazł się fragment przedstawiający scenę erotyczną z udziałem islamskiego proroka wraz z komentarzem, że „Mahomet nie zabraniał współżycia seksualnego z martwymi osobami czy też z żywymi zwierzętami” ${ }^{37}$;

- nałożenie grzywny w wysokości 480 euro za wypowiedź na otwartym seminarium dyskusyjnym na temat islamu, w trakcie którego prelegentka powiedziała, że Mahomet „miał wiele kobiet” i „lubił to robić z dziećmi” ${ }^{38}$.

\section{Przykłady niedopuszczalnych ingerencji w wolność wypowiedzi w celu ochrony uczuć religijnych}

Z kolei za pogwałcenie wolności wypowiedzi ETPC uznał:

- zasądzenie grzywny w wysokości 15000 koron (ok. 375 euro) od dziennikarza, który w artykule prasowym skrytykował katolickiego arcybiskupa za sprzeciw wobec bluźnierczego plakatu zapowiadającego premierę nowego

\footnotetext{
${ }^{33}$ Wyrok z 10 lipca 2003 r., Murphy p. Irlandii: $\$ 73$.

${ }^{34}$ Wyrok ETPC z 20 września 1994 r., Otto-Preminger-Institut p. Austrii.

${ }^{35}$ Wyrok ETPC z 25 listopada 1996 r., Wingrove p. Zjednoczonemu Królestwu.

36 Wyrok ETPC z 10 lipca 2003 r., Murphy p. Irlandii.

37 Wyrok ETPC z 13 września 2005 r., I. A. p. Turcji.

38 Wyrok ETPC z 25 października 2018 r., E. S. p. Austrii.
} 
filmu w kinach. Dziennikarz wypomniał hierarsze współpracę ze służbami bezpieczeństwa w czasach komunizmu oraz wyraził zdziwienie, dlaczego katolicy nie opuszczą organizacji kierowanej przez takiego „ogra”39;

- zasądzenie od publicysty odszkodowania w wysokości 1 franka oraz obowiązku zapłaty 10000 franków tytułem zwrotu kosztów chrześcijańskiemu stowarzyszeniu, które złożyło skargę na jego krytyczny artykuł wobec encykliki Jana Pawła II Veritatis splendor. W ocenie autora zawarta w encyklice teza, że Stary Testament wypełnił się w Nowym Testamencie, jest powtarzana przez Kościół katolicki od wielu lat, przez co stała się źródłem antysemityzmu i „przygotowała grunt” pod Holokaust ${ }^{40}$;

- nałożenie grzywny w wysokości 580 euro na firmę prowadzącą kampanię reklamową z udziałem aktora wcielającego się w Jezusa w spodniach dżinsowych, gdzie jedno z haseł brzmiało: „Jezu, co za spodnie!”41.

\section{AKTUALNE SPRAWY DOTYCZACE POSZANOWANIA UCZUĆ RELIGIJNYCH OCZEKUJĄCE NA ROZSTRZYGNIĘCIE ETPC}

20 czerwca 2019 r. ETPC zakomunikował rządowi hiszpańskiemu sprawę Asociación Española de Abogados Cristianos p. Hiszpanii ${ }^{42}$. Sprawa dotyczy „artysty”, który na publicznej wystawie udostępnionej mu przez władze miasta przedstawił zdjęcia, na których leżał nago na tle słowa „pederastia” ułożonego z konsekrowanych opłatków (Komunii świętej traktowanej przez katolików jako Ciało Chrystusa), która osobiście wyniósł z różnych kościołów katolickich, podszywając się pod wiernego na mszach. Chrześcijańska organizacja pozarządowa złożyła do organów ścigania zawiadomienie o przestępstwie obrazy uczuć religijnych i profanacji, ale sędzia śledczy odmówił wszczęcia śledztwa $\mathrm{z}$ uwagi na brak znamion czynu zabronionego. W skardze organizacja podniosła zarzut naruszenia art. 8, art. $9 \mathrm{i}$ art. 14 EKPC. Sprawa ma charakter precedensowy, ponieważ po raz pierwszy ETPC oceni, czy prawo do poszanowania uczuć religijnych wywiedzione z art. 9 EKPC może stanowić samodzielny zarzut skargi. Jak zostało to już powiedziane, dotychczas prawo do poszanowania uczuć religijnych pojawiało się w orzecznictwie ETPC jedynie jako wartość usprawiedliwiająca w pewnych przypadkach ograniczenie wolności słowa.

7 września 2017 r. ETPC zakomunikował rządowi polskiemu sprawę $R a b$ czewska p. Polsce ${ }^{43}$. Sprawa dotyczy piosenkarki Doroty „Dody” Rabczewskiej, która w 2009 r. w wywiadzie prasowym powiedziała, że „bardziej wierzy w di-

${ }^{39}$ Wyrok ETPC z 31 października 2006 r., Klein p. Stowacji.

${ }^{40}$ Wyrok ETPC z 31 stycznia 2006 r., Giniewski p. Francji.

${ }^{41}$ Wyrok ETPC z 30 stycznia 2018 r., Sekmadienis p. Litwie.

${ }^{42}$ Komunikat ETPC z 20 czerwca 2019 r., <https://hudoc.echr.coe.int/eng\#\{,tabview”:[,document"],"itemid":[,001-194551"]\} [dostęp: 2.02.2020].

${ }^{43}$ Komunikat ETPC z 7 września 2017 r., <https://hudoc.echr.coe.int/eng\#\{,fulltext”:[,Rabczewska"],"documentcollectionid2”:[,GRANDCHAMBER”,"COMMUNICATEDCASES”],"itemid":[,001-177325”]> [dostęp: 27.09.2019]. 
nozaury niż w Biblię”, ponieważ „ciężko wierzyć w coś, co spisał jakiś napruty winem i palaccy jakieś zioła”. W 2010 r. prokuratura postawiła jej zarzut obrazy uczuć religijnych. W odpowiedzi na akt oskarżenia piosenkarka wyjaśniła, że nie miała intencji nikogo obrazić - według niej „napruty” oznacza „pozytywnie nastawiony”, „wino było mszalne”, a „zioła z pewnością mogły być lecznicze". W 2012 r. została skazana przez sąd rejonowy na karę grzywny w wysokości 5000 zł, a jego wyrok został utrzymany w mocy przez sąd okręgowy. Piosenkarka zaskarżyła skargą konstytucyjną stanowiący podstawę jej skazania art. 196 Kodeksu karnego do Trybunału Konstytucyjnego, który jednak potwierdził zgodność przepisu z Konstytucja. W sprawie Doroty Rabczewskiej ETPC w Strasburgu będzie miał kolejną okazję do wypowiedzenia się na temat relacji pomiędzy prawem do poszanowania uczuć religijnych a wolnością słowa.

\section{WNIOSKI}

Mając na względzie powyższe omówienie europejskiego standardu w zakresie relacji między wolnością słowa a ochroną uczuć religijnych, można postawić następujące wnioski:

Z wolności religii wynika prawo do poszanowania (ochrony) uczuć religijnych osób wierzących. Uczucia religijne stanowią immanentną część wewnętrznej sfery wolności religii osoby wierzącej (forum internum). Wiara w istotę boska, otaczanie czcią świętego znaku, figury, obrazu czy księgi, opiera się bowiem na uczuciach - szacunku, bojaźni, a czasem nawet i miłości najbardziej osobistych i intymnych przeżyciach osoby wierzącej. Skoro forum internum wolności religii jest uznawane współcześnie za tak ważną wartość, że całkowicie wyklucza się poddanie tej sfery jakiejkolwiek prawnej reglamentacji ${ }^{44}$, to państwo powinno osobom wierzacym zapewnić instrumenty ochrony ich najskrytszych uczuć i przekonań przed upokarzajacymi atakami. Uczucia religijne są również ściśle związane z zewnętrzną sferą wolności religii osoby wierzacej (forum externum), albowiem w momencie utraty uczuć religijnych wobec obiektu kultu, słabnie, a czasem nawet i ustaje wola praktykowania określonej religii (jej „uzewnętrzniania”). Można zatem powiedzieć, że posiadanie uczuć religijnych w odniesieniu do szeroko rozumianych obiektów kultu jest warunkiem sine qua non wyznawania zdecydowanej większości religii (chrześcijaństwa, islamu, judaizmu) ${ }^{45}$. Innymi słowy, im większe przyzwolenie na obrazę uczuć religijnych w przestrzeni publicznej, tym mniej chętnie ludzie będą korzystali z wolności religii - jest to swego rodzaju zjawisko „efektu mrożącego" w stosunkach horyzontalnych.

44 Brzozowski, Krzywoń, Wiącek (2019): 201.

45 Natomiast niekoniecznie musi tak być w przypadku buddyzmu, który jako religia bez osobowego Boga różni się od wyżej wymienionych. 
Wypowiedzi obraźliwe wobec religii są w tym kontekście nie tylko forma korzystania z wolności wypowiedzi, ale mogą być również ingerencją w osobisty stosunek emocjonalny i intelektualny łączący osobę wierząca z obiektem kultu. Ocena dopuszczalności takiej ingerencji wymaga wyważenia między dwoma wartościami: wolnością słowa obejmującą również prawo do krytyki religii a wolnością religii obejmujaccą także prawo do poszanowania uczuć religijnych.

Nie bez znaczenia jest rozróżnienie materialnych (np. Biblia, Koran, Hostia, krzyż, ołtarz) i niematerialnych (Bóg, Matka Boża, święci, prorocy) przedmiotów czci religijnej, a także sposób ich znieważenia. W pierwszym przypadku szczególnie istotna jest okoliczność, czy znieważenie nastapiło wyłącznie $\mathrm{w}$ formie ustnej bądź pisemnej wypowiedzi, czy polegało również na fizycznym sprofanowaniu przedmiotu czci. Charakter przedmiotu czci, jak również forma jego potraktowania, powinny być brane pod uwagę przy ustalaniu przez sąd lub inny właściwy organ sankcji za bezprawną ingerencję w dobro osobiste, jakimi są uczucia religijne (obrazę uczuć religijnych).

Wolność wypowiedzi w rozumieniu przyjętym w EKPC nie stoi na przeszkodzie stworzeniu mechanizmów ochrony uczuć religijnych jednostek. Państwom przysługuje w tej sferze margines swobody co do wyboru formy ochrony, która może mieć charakter cywilny, administracyjny, a nawet karny. O zakresie marginesu swobody decyduje w dużym stopniu kontekst społeczno-kulturowy w danym państwie, w tym w szczególności religijność danego społeczeństwa. Im bardziej ludzie w danym kraju są wrażliwi na punkcie spraw religijnych, tym głębiej może państwo ingerować w wolność wypowiedzi w celu zapewnienia poszanowania uczuć religijnych i zagwarantowania pokoju religijnego.

W świetle stanowiska ETPC w cytowanych sprawach Otto-Preminger, Wingrove, I. A. oraz E.S. za bezproduktywnie obraźliwe należy uznać w szczególności takie wypowiedzi, które upokarzają osoby wierzące, uniemożliwiając podjęcie im jakiejkolwiek polemiki. W szczególności zasadniczo można przyjąć domniemanie, że wypowiedzi ukazujące obiekty kultu religijnego w seksualnym kontekście nie wnoszą żadnego wkładu w debatę publiczna, lecz służą wyłącznie upokorzeniu osób wierzących. Z ekspresją o charakterze pornograficznym czy erotycznym nie da się merytorycznie dyskutować, nie ma pola do polemiki, wymiany argumentów.

W świetle stanowiska ETPC w cytowanych sprawach Handyside, Prager i Obershlick, Standard Verlagsgesellschaft, Klein oraz Giniowski dopuszczalne są nawet kontrowersyjne, szokujące, tendencyjne i krzywdzące wypowiedzi na temat religii, pod warunkiem że wnoszą one choćby minimalny wkład w debatę publiczną i mogą stać się przedmiotem merytorycznej polemiki. Nie można się więc zgodzić ze stanowiskiem formułowanym przez niektórych przedstawicieli polskiej doktryny, że sprzeczne z prawem są wypowiedzi „wyszydzające bądź wyśmiewające dogmaty religijne, kwestionujące prawdziwość objawień, poddające w wątpliwość prawdy wiary i sens nakazów religijnych" ${ }^{46}$. Taki pogląd de facto uniemożliwiałby zabieranie głosu w sprawach religijnych

46 Sobczak (2001). 
ateistom i agnostykom, którzy z natury rzeczy kwestionują istnienie Boga, podaja w wątpliwość prawdy wiary i sens nakazów religijnych. Nie można też zgodzić się ze stanowiskiem, że „uwagi krytyczne [pod adresem religii] winny mieć charakter wyważony, wolny od napastliwości, rzeczowy" ${ }^{47}$, które stoi w jaskrawej sprzeczności z utrwaloną linią strasburska, mówiąca, że wolność słowa chroni także wypowiedzi, które obrażaja, oburzają i wzbudzaja niepokój w społeczeństwie. Niezależnie od tego, sam jestem zdania, że wolność słowa jest interpretowana współcześnie zbyt szeroko (podzielam stanowisko wyrażone w cytowanym powyżej zdaniu odrębnym Matschera i Vilhjálmssona do wyroku Oberschlick p. Austrii nr 2).

W świetle stanowiska ETPC w sprawie Sekmadienis można z całą stanowczością powiedzieć, że wykorzystanie symbolu religijnego w celach komercyjnych nie może per se usprawiedliwiać nałożenia kary za obrazę uczuć religijnych - ani w trybie administracyjnym, ani tym bardziej w trybie karnym.

W świetle stanowiska ETPC w sprawie Sekmadienis przed nałożeniem kary za naruszenie obrazy uczuć religijnych przez organ władzy publicznej (np. Przewodniczącego KRRiT) należy dogłębnie zbadać, czy ingerencja w wolność wypowiedzi jest w konkretnych okolicznościach konieczna. W związku z tym:

- orzeczenia i decyzje nakładające kary finansowe za obrazę uczuć religijnych powinny być szczegółowo uzasadnione, ze wskazaniem poważnych i sprecyzowanych powodów, dla których uznano, że w konkretnych okolicznościach dana wypowiedź była obraźliwa i musiała zostać ukarana. Ciężar udowodnienia, że wypowiedź obiektywnie obrażała uczucia religijne, spoczywa na organie;

- jeśli wypowiedź będąca przedmiotem oceny może obrażać wyznawców różnych religii, należy zasięgnąć opinii przedstawicieli wszystkich z nich. Przykładowo w przypadku wypowiedzi godzącej w uczucia chrześcijańskie do pełnej oceny obraźliwego charakteru wypowiedzi nie wystarczy zapoznanie się ze stanowiskiem Kościoła katolickiego. Nierozstrzygnięta pozostaje kwestia kary pozbawienia wolności za obrazę uczuć religijnych. Ani polski Trybunał Konstytucyjny, ani Europejski Trybunał Praw Człowieka nie miał jak dotąd okazji do wypowiedzenia się na ten temat.

Janusz Roszkiewicz

Uniwersytet Warszawski

j.roszkiewicz@wpia.uw.edu.pl

https://orcid.org/0000-0001-5055-2215

Brzozowski W., Krzywoń, A., Wiącek, M. (2019). Prawa człowieka. Warszawa.

Bychawska-Siniarska D. (2017). Protecting the Right to Freedom of Expression under the European Convention on Human Rights. A Handbook for Legal Practitioners. Council of Europe.

Clooney A., Webb, P. (2017). The right to insult in international law. Columbia Human Rights Law Review 48(2): 1-55.

Dijk P. van, Hoof, F. van, Rijn, A. van, Zwaak, L. (2018). Theory and Practice of the European Convention on Human Rights. Cambridge-Antwerp-Portland.

${ }^{47}$ Sobczak (2001). 
Evans, C. (2001). Freedom of Religion under the European Convention on Human Rights. Oxford. Frowein, J., Peukert, W. (1996). Europäische Menschenrechtskonvention. EMRK-Kommentar. Kehl am Rhein.

Garlicki L., Hofmański, P., Wróbel, A. (2010). Konwencja o Ochronie Praw Człowieka i Podstawowych Wolności. Komentarz do artykułów 1-18. Tom 1: Komentarz. Wersja elektroniczna Legalis. Warszawa: uwaga z nb. 7 do art. 10, uwaga z nb. 21 do art. 9.

Hucał, M. (2012). Wolność sumienia i wyznania w orzecznictwie Europejskiego Trybunału Praw Człowieka. Warszawa.

Letsas, G. (2012). Is there a right not to be offended in one's religious beliefs? [w:] L. Zucca (ed.), Law, State and Religion in the New Europe Debates and Dilemmas. Cambridge: 239-260.

Meyer-Ladewig, J., Nettesheim, M., Raumer, S. von (2017). EMRK - Europäische Menschenrechtskonvention. Handkommentar. Basel.

Milanovic, M. (2018). Legitimizing blasphemy laws through the backdoor: the European Court's judgment in E.S. v. Austria. Blog of the European Journal of International Law, 29.10.2018, $<$ https://www.ejiltalk.org/legitimizing-blasphemy-laws-through-the-backdoor-the-european-courts-judgment-in-e-s-v-austria/> [dostęp: 5.02.2020].

Nowińska, E. (2007). Wolność wypowiedzi prasowej. Warszawa.

Peers, S. (2018). Freedom to insult? Balancing freedom of expression with religious tolerance in ECHR case law. EU Law Analysis Blog, 19.12.2018. <http://eulawanalysis.blogspot. com/2018/10/freedom-to-insult-balancing-freedom-of.html> [dostęp: 5.02.2020].

Sobczak, W. (2013). Wolność myśli, sumienia i religii. Poszukiwanie standardu europejskiego. Toruń.

Schabas, W.A. (2015). The European Convention on Human Rights: A Commentary. Oxford.

Skrzydło, J. (2013). Wolność słowa w orzecznictwie Sądu Najwyższego Stanów Zjednoczonych i Europejskiego Trybunału Praw Człowieka: analiza porównawcza. Torun.

Smet, S. (2018). E.S. v. Austria: freedom of expression versus religious feelings, the sequel. Strasbourg Observers, 7.11.2018. <https://strasbourgobservers.com/2018/11/07/e-s-v-austria-freedom-of-expression-versus-religious-feelings-the-sequel/> [dostęp: 5.02.2020].

Sobczak, J. (2001). Radiofonia i telewizja. Komentarz. Wersja elektroniczna Lex: uwaga nr 6 do art. 18 .

Uitz, R. (2007). Freedom of Religion in European Constitutional and International Case Law. Strasburg.

Wacławczyk, W. (2009). Wolność słowa: wybrane zagadnienia. Toruń.

Warchałowski, K. (2004). Prawo do wolności myśli, sumienia i religii w Europejskiej Konwencji Praw Człowieka i Podstawowych Wolności. Lublin.

\section{THE RIGHT TO RESPECT FOR RELIGIOUS FEELINGS IN THE LIGHT OF THE CONVENTION ON HUMAN RIGHTS AND FUNDAMENTAL FREEDOMS}

$\mathrm{Sum}$ m a r y

This article is devoted to the right to respect for religious feelings, which is a derivative of freedom of religion. In the light of the case-law of the European Court of Human Rights in Strasbourg, the protection of religious feelings constitutes a value that justifies the restriction of freedom of speech. The law protects the feelings of believers primarily from statements that are gratuitously offensive. The concept of gratuitous offensiveness is interpreted relatively narrowly, and therefore expressions that are shocking, controversial, critical of religion or questioning dogmas, are fully allowed and within the limits of freedom of speech. The most appropriate form of protection of religious feelings are civil law sanctions, while criminal sanctions should apply only as a last resort in the case of statements calling for violence or leading to a serious disturbance of public order.

Keywords: freedom of religion; gratuitously offensive expressions; protection of religious feelings; public order; violence 